\title{
PERAN TEKNOLOGI DALAM MENDUKUNG PEMBELAJARAN BAHASA INGGRIS DI SEKOLAH DASAR
}

\author{
I PUTU ANDRE SUHARDIANA \\ Institut Hindu Dharma Negeri Denpasar \\ Email: putuandresuhardiana@gmail.com
}

diterima 1 April 2019, direvisi 10 April 2019, diterbitkan 29 April 2019

\begin{abstract}
The new era presents teachers new challenges and responsibilities. The tradition of teaching English has improved dramatically with the inclusion of various types of advanced technology. Technology provides numerous choices such as making teaching interesting and more productive. Technology is one of the most influential boosters of social and language change. Since the use of English has progressed in popularity, the demand for qualified teachers to teach English is unquestionably required. It is true that there are teachers who use 'sophisticated' technology, although most of them still teach in the traditional way. None of these traditional behaviors is bad or damaging to students. In fact, until now they proved it useful too. However, there are various opportunities for students to gain self-confidence to practice and expand themselves, particularly for those who are learning English as a foreign language that learns the language for more than just having fun. If they want to be able to follow the learning process and gain more confidence, they must step into the world of multimedia technology.
\end{abstract}

Keywords: Technology, English Language Learning, Primary School

\section{PENDAHULUAN}

Abad ke 21 adalah zaman globalisasi dan penting untuk memahami berbagai bahasa asing. Bahasa Inggris, dalam hal ini menjadi yang pertama. Pengajaran Bahasa Inggris telah berlangsung selama bertahun-tahun dan signifikansinya terus tumbuh serta didorong sebagian oleh pengaruh Internet. Penelitian Eaton (2010:35) menunjukkan bahwa pada tahun 2000 ada sekitar satu miliar pelajar bahasa Inggris, tetapi satu dekade kemudian jumlahnya meningkat dua kali lipat. Data ini menunjukkan lonjakan dalam pembelajaran bahasa Inggris, yang telah mencapai puncaknya pada tahun 2010. Penelitian yang sama menunjukkan bahwa lebih dari $80 \%$ informasi yang disimpan di internet menggunakan bahasa Inggris.

Dengan perkembangan pesat sains dan teknologi, munculnya teknologi multimedia dan aplikasinya untuk mengajar, menampilkan audio, visual, serta efek animasi membawa warna tersendiri dalam pengajaran bahasa Inggris dan menetapkan platform yang menguntungkan untuk reformasi dan eksplorasi pada model pengajaran bahasa Inggris di era baru. Terbukti bahwa teknologi multimedia memainkan peran positif dalam mempromosikan aktivitas dan inisiatif siswa dalam proses pembelajaran bahasa Inggris di kelas. Dockstader (2008:76) menyatakan bahwa inovasi teknologi telah berjalan dengan baik dengan pertumbuhan bahasa Inggris 
dan mengubah cara siswa berkomunikasi. Adalah wajar untuk menyatakan bahwa pertumbuhan internet telah memfasilitasi pertumbuhan bahasa Inggris dan hal ini terjadi pada saat komputer tidak lagi menjadi domain eksklusif dari beberapa orang yang berdedikasi, tetapi lebih tersedia untuk banyak orang. LarsenFreeman (2011:34) menegaskan bahwa dengan ini telah terjadi proliferasi literatur yang sangat signifikan mengenai penggunaan teknologi dalam pengajaran bahasa Inggris. Sebagian besar penelitian ilmiah terpublikasi pada Jurnal dengan tegas menerima teknologi sebagai bagian paling penting dalam mengajar. Artinya, ada kecenderungan untuk menekankan proses pembelajaran pada peran teknologi yang tak terelakkan dalam pedagogi. Dan sebagai hasilnya jika kita mengabaikan perkembangan teknologi, maka ketertinggalan kita akan terus berlanjut dan akan sulit untuk dapat terkejar, terlepas dari segala disiplin atau cabang ilmu yang dipelajari. Untuk alasan ini, penting bagi guru bahasa Inggris untuk memahami dan menguasai teknologi terbaru dan terbaik dan memiliki pengetahuan penuh tentang apa yang tersedia dalam situasi tertentu. Guru dapat menggunakan teknologi multimedia untuk memberikan ceramah yang lebih berwarna dan menstimulasi.

Ada banyak teknik yang dapat diterapkan dalam berbagai tingkat situasi pembelajaran bahasa. Beberapa berguna untuk pengujian dan pendidikan jarak jauh, dan beberapa untuk mengajar bahasa Inggris, berbicara bahasa Inggris, membaca, mendengarkan, atau menafsirkan. Prinsip pengajaran haruslah untuk menghargai teknologi baru dan memiliki fungsi sebagai penyedia hal yang sangat berguna dan tidak pernah membiarkan mesin mengambil alih peran guru atau membatasi fungsi di mana cara yang lebih tradisional lebih unggul (Pourhossein, 2017:32). Ada berbagai alasan mengapa semua pembelajar bahasa Inggris dan juga guru harus tahu bagaimana memanfaatkan teknologi modern. Di sini kita juga perlu menekankan bahwa teknologi baru berkembang dan menyebar dengan sangat cepat sehingga kita tidak dapat menghindari ketertarikan dan pengaruh mereka dalam bentuk apa pun.

Pengajaran secara tradisional sedikit banyak menghambat kemampuan siswa untuk memahami bahasa tertentu dan juga memahami struktur, makna, dan fungsi bahasa, serta membuat siswa penerima pengetahuan pasif. Jadi, mereka lebih sulit untuk mencapai target komunikasi. Dengan instruksi guru yang mengarahkan pola pikir dan memotivasi siswa, teknologi multimedia membantu dalam integrasi pengajaran dan pembelajaran serta memberikan siswa kesempatan yang lebih besar. Jadi pengajaran teknologi multimedia secara unik menginspirasi pemikiran positif siswa dan keterampilan komunikasi dalam praktik social (Solanki, 2012:22). Pembelajaran berbasis multimedia dapat menawarkan informasi yang berlimpah kepada siswa; lebih banyak daripada buku teks, dan membantu mereka untuk menampilkan latar belakang budaya yang jelas, konten yang kaya, dan materi bahasa yang benar-benar hidup, yang jauh lebih alami dan lebih dekat dengan kehidupan. Tidak hanya pembelajar dapat meningkatkan kemampuan mendengar mereka, tetapi juga belajar budaya lain. Memahami informasi melalui berbagai saluran.

Susikaran

(2012:142)

menyatakan bahwa pengajaran berbasis 
multimedia memperkaya konten pengajaran dan memanfaatkan waktu kelas sebaik-baiknya dan mematahkan pola pengajaran "teacher-centered" dan secara fundamental meningkatkan efisiensi kelas. Karena kelas besar, sulit bagi siswa untuk memiliki komunikasi berbicara. Model pengajaran tradisional terutama menekankan pada instruksi guru, dan informasi yang diberikan terbatas karena kelas tradisional. Sebaliknya, teknologi multimedia melampaui ruang dan waktu, menciptakan lingkungan yang lebih hidup, visual, dan otentik untuk pembelajaran bahasa Inggris, merangsang inisiatif siswa dan menghemat waktu siswa di kelas, juga meningkatkan informasi bagi para siswa di kelas.

Pengajaran berbasis multimedia menekankan peran siswa, dan meningkatkan pentingnya "interaksi" antara guru dan siswa. Fitur utama dari pengajaran berbasis multimedia adalah untuk melatih dan meningkatkan kemampuan siswa untuk mendengarkan dan berbicara, dan untuk mengembangkan kompetensi komunikatif mereka. Selama proses ini, peran guru sebagai fasilitator sangat menonjol. Menggunakan multimedia dalam penciptaan konteks menciptakan platform yang baik untuk interaksi antara guru dan siswa, sementara pada saat yang sama menyediakan lingkungan bahasa yang meningkatkan pada model pengajaran kelas tradisional (Sabzian \& Sodouri, 2013:121). Dengan cara ini, guru di kelas tidak lagi secara membabi buta memasukkan informasi dan memaksa siswa menerimanya dengan cara pasif.

Pengajaran berbasis multimedia menciptakan konteks untuk pengajaran bahasa. Metode ini membuat kelas hidup dan menarik, serta mengoptimalkan organisasi kelas.
Multimedia memiliki fitur sendiri seperti visibilitas dan keaktifan. Selama proses pengajaran bahasa Inggris, bunyi dan gambar dapat disatukan, hal ini dapat meningkatkan inisiatif dari guru dan siswa (Parvin:2015:81). Ketika menggunakan perangkat lunak multimedia, guru dapat menggunakan gambar untuk memperkaya konten kelas, dan juga memberikan konteks yang berbeda dalam proses pembelajaran. Siswa di kelas dapat menggunakan multimedia untuk memahami materi dengan cara yang jelas. Melalui seluruh proses interaktif, jelas bahwa menggunakan multimedia dalam mempelajari bahasa Inggris secara efektif dapat memelihara minat siswa dalam belajar bahasa Inggris, serta meningkatkan minat guru dalam melaksanakan pengajaran bahasa Inggris. Selain itu, pengajaran multimedia juga fleksibel. Jelas bahwa konteksnya dapat dibuat tidak hanya di kelas, tetapi juga di luar kelas. Pengajaran bahasa Inggris dengan memanfaakan multimedia juga dapat menciptakan lingkungan pembelajaran yang berfokus pada bimbingan guru dan berpusat pada siswa. Siswa pasti memiliki beberapa masalah dalam pengajaran di kelas, yang dapat ditangani di bawah bimbingan guru. Dalam keadaan seperti itu, siswa dapat menggunakan teknologi untuk keuntungan mereka, seperti pemanfaatan jaringan untuk menghubungi guru dan menerima jawaban melalui email.

\section{PEMBAHASAN}

\subsection{Penggunaan Teknologi dalam Pengajaran Bahasa Inggris}

Di dunia digital, di mana segalanya berada di bawah kendali Internet, sulit untuk mengabaikan keberadaan dan kontribusi teknologi terhadap pengajaran bahasa Inggris. 
Media seperti video, podcast, lembar kerja, e-learning, aplikasi, dan situs web, serta perangkat teknologi lainnya sangatlah bermanfaat. Pembelajaran bahasa Inggris adalah proses pengajaran bahasa kedua yang tidak gampang: berbagai faktor berkontribusi dan digabungkan bersama untuk mencapai keberhasilan dari usaha ini. Untuk menghasilkan hasil yang baik, para guru harus mencurahkan banyak waktu dan upaya untuk menentukan metode pengajaran yang paling memuaskan, cocok, dan efektif. Tidak hanya realitas sehari-hari yang dipengaruhi oleh teknologi baru, tetapi juga pengembangan keterampilan bahasa mulai bergantung padanya (Pourhossein, 2014:37). Karena jumlah pembelajar bahasa Inggris semakin meningkat, untungnya, semakin banyak alat modern dan perangkat teknologi yang diimplementasikan ke dalam proses mengajar. Saat ini, para guru cenderung menggunakan alat-alat seperti video, podcast, lembar kerja, elearning, aplikasi, dan situs web, yang dapat diakses melalui perangkat elektronik seperti komputer pribadi, atau telepon selular. Penemuan ini memfasilitasi lingkungan kelas dan diversifikasi kegiatan belajar.

\subsection{Multimedia: Teknik dalam Proses Pengajaran di Kelas}

Berbagai multimedia dapat diimplementasikan untuk meningkatkan kualitas pendidikan dan meningkatkan efektivitas pengajaran bahasa Inggris. Kebosanan dan rutinitas hanya menggunakan buku pelajaran secara berulang-ulang dengan jenis latihan yang sama dapat dengan mudah dihindari. Karena masalah pemahaman bahasa lisan sangat penting, guru harus mencoba berbagai sumber. Buku yang bersifat tradisional biasanya menawarkan pengerjaan latihan soal benar atau salah, yang tidak benarbenar memberikan rasa komunikasi yang nyata (Kirkgoz, 2006:41). Siswa sangat sering mengeluh bahwa pembelajaran yang hanya berjalan bersama dengan buku-buku pelajaran tampaknya tiruan dan palsu. Untungnya, berbagai macam media pembelajaran gratis yang dibuat khusus untuk pembelajar bahasa, saat ini dapat diakses di iTunes, YouTube, SoundCloud, dll (Keser \& Ozdamli, 2012:11). Sumber terpercaya lain yang dapat digunakan untuk tujuan praktik mendengarkan adalah radio. Media ini menawarkan siaran berita dan wawancara yang tersedia di situs web mereka. Selain itu, guru dapat juga menggunakan lagu yang diputar saat ini di radio karena sebagian besar siswa dapat mengenalinya dengan mudah dan lebih akrab dengan lirik meskipun mereka tidak tahu arti dibalik kata-kata tersebut. Saat ini, hampir semua orang memiliki komputer atau smartphone. Karena fakta ini, siswa dapat membuat rekaman sendiri yang memberi mereka kesempatan untuk mempraktekkan pelafalan mereka.

Menurut Eady (2013:34), peran kunci dalam menghilangkan kegiatan yang monoton dari kelas ditempati oleh video, yang mendukung perluasan kosakata dan pengembangan keterampilan mendengarkan. Sementara anak-anak lebih memilih menonton kartun atau cerita animasi, pelajar yang lebih tua lebih mungkin menonton film dokumenter tentang sebuah perjalanan. Video yang berisi lirik dari sebuah lagu sangat menghibur dan memberikan banyak pilihan mengingat fakta bahwa guru dapat menggunakan lagu favorit siswa. Sebagai hasil dari kegiatan tersebut, siswa dapat memiliki pengalaman pembelajaran bahasa tidak hanya secara audio tetapi juga secara visual. Ini 
memberi mereka konteks yang lebih baik dan wawasan tentang penggunaan bahasa Inggris secara alami.

Mayoritas siswa yang lebih muda memiliki akses untuk mendapatkan informasi melalui internet sebanyak mungkin. Dalam hal ini guru dapat menggunakan sumber daya yang tak terhitung jumlahnya yang dapat menstimulasi dan meningkatkan setiap aspek keterampilan berbahasa. Beberapa game berbasis internet misalnya, menyediakan lingkungan kelas dengan beragam permainan yang gratis dan tersedia untuk semua orang. Permainan ini merancang siswa untuk berlatih dan memeriksa misalnya kosakata sasaran, konstruksi tata bahasa tertentu, atau pemahaman teks. Selain itu, siswa memiliki kesempatan untuk melatih keterampilan mereka di rumah dengan mengunduh aplikasi dan game di ponsel atau komputer mereka. Guru bahkan mungkin menampilkan permainan ini di papan tulis interaktif dan melibatkan seluruh kelas. Menurut Patel (2013:46), konsep peningkatan keterampilan menulis dapat dilakukan dengan mendorong siswa untuk membuat blog online juga layak dipertimbangkan. Platform blog seperti Blogger atau WordPress dapat memberi siswa kesempatan untuk membuat blog secara gratis. Terkadang siswa menganggap blogging menarik dan mendorong karena mereka dapat menulis tentang apa pun yang mereka anggap menarik. Fakta bahwa tidak hanya guru dapat membaca tulisan virtual mereka, tetapi pada dasarnya semua orang dengan akses ke Internet, membuat mereka lebih berupaya menulis. Mendapatkan umpan balik dari audiens yang lebih besar mungkin memiliki pengaruh positif pada pengembangan keterampilan seseorang juga. Jika ide blogging mingguan atau harian tidak menarik bagi siswa, mereka dapat menggunakan blog mereka sebagai portofolio digital dari karya terbaik mereka.

\subsection{Integrasi Teknologi dalam Kelas}

Dalam beberapa tahun terakhir, perubahan revolusioner telah terjadi di ruang kelas di samping penggunaan metode pengajaran karena metode pengajaran saja tidak cukup untuk mengajar bahasa Inggris secara efektif. Dengan lingkungan kelas yang terencana dengan baik, para siswa belajar bagaimana belajar dengan baik dan efektif. Baik cara mengajar dan belajar bahasa Inggris telah berubah. Saat ini, terbukti bahwa lingkungan kelas berbasis teknologi dalam proses pengajaran lebih bermanfaat daripada kelas berbasis ceramah. Guru perlu mencari cara menggunakan teknologi sebagai alat pembelajaran untuk siswa mereka bahkan jika mereka tidak menguasai teknologi dan tidak dapat bertindak sebagai ahli.

Baytak (2011:26) memberikan pendapat bahwa penggunaan teknologi telah sangat mengubah teknik pengajaran bahasa Inggris. Teknologi menyediakan begitu banyak pilihan seperti membuat pengajaran menjadi menarik dan juga membuat pengajaran menjadi lebih produktif dalam hal peningkatan kemampuan siswa dalam menggunakan bahasa Inggris. Dalam ruang kelas tradisional, guru biasanya berdiri di depan siswa dan memberikan ceramah dan juga memberikan penjelasan dan instruksi dengan menggunakan papan tulis. Teknik ini perlu sedikit dimodifikasi sehubungan dengan perkembangan teknologi. Menurut Gençlter (2015:24), penggunaan teks-teks multimedia di kelas membantu siswa untuk menjadi semakin akrab dengan kosakata akademik dan struktur bahasa. Penggunaan multimedia yang 
dijelaskan di sini menggunakan teksteks cetak, film, dan internet untuk mengembangkan dan meningkatkan kemampuan berbahasa Inggris dan pengetahuan. Penggunaan teks-teks cetak, film, dan internet memberi siswa kesempatan untuk mengumpulkan informasi dan memperkenalkannya ke berbagai bahan untuk analisis dan interpretasi bahasa dan konteks. Internet menyajikan kepada siswa berbagai koleksi teks bahasa Inggris di banyak disiplin. Menurut Costley (2014:47), penggunaan internet dapat memberikan manfaat dari peningkatan motivasi siswa. Selain itu, penggunaan film dalam pengajaran dapat membantu siswa untuk memahami topik dengan antusias dan mengembangkan pengetahuan mereka. Terkadang guru mencoba mendorong siswa mereka untuk belajar dari dan tentang teknologi, tetapi mengabaikan aspek yang paling penting, yaitu belajar dengan teknologi. Siswa dapat belajar dengan penuh makna ketika teknologi digunakan dalam proses belajar melalui penggunaan komputer, internet, dan lain sebagainya. Ketika siswa belajar dengan teknologi, itu membantu mereka untuk mengembangkan tatanan berpikir dan keterampilan riset yang lebih tinggi. Oleh karena itu, kombinasi yang tepat antara multimedia dan metodologi pengajaran dapat menarik perhatian siswa terhadap pembelajaran bahasa Inggris.

\subsection{Peran Teknologi dalam Peningkatan Keterampilan Bahasa Inggris}

Penerapan berbagai media yang melibatkan penggunaan teknologi baru semakin mendapatkan dukungan dari berbagai pihak dan sering dilakukan, tidak hanya di sekolah swasta, tetapi juga di sekolah umum, di mana pelajaran bahasa Inggris lebih sering didukung oleh materi digital (Arifah, 2014:74). Penggunaan berbagai media yang dijelaskan di atas tergantung pada ketersediaan perangkat teknologi. Mulai dari hal yang paling mendasar, yaitu komputer yang memungkinkan untuk menampilkan gambar untuk semua siswa dapat melihatnya, misalnya dengan bantuan proyektor, papan interaktif, atau satu set TV. Koneksi internet tidak selalu diperlukan, meskipun, itu membuat pelajaran lebih mudah untuk dipersiapkan dan lebih cepat dalam hal interaksi. Seorang guru yang dilengkapi dengan perangkat semacam itu dapat memperoleh manfaat dari sumber daya digital dan peralatan secara efisien. Siswa, menggunakan perangkat teknologi modern secara individual, dapat merevisi dan merasakan materi otentik yang disediakan oleh guru baik selama berada kelas ataupun di rumah. Hal ini tentunya bertujuan membuat siswa lebih terlibat dan puas dengan hasil yang diperoleh. Itu sebabnya, baik siswa maupun guru harus memiliki akses ke berbagai multimedia melalui perangkat teknologi yang berbeda.

\subsection{Manfaat Penggunaan Teknologi dalam Pengajaran Bahasa Inggris}

Profitabilitas penggunaan

multimedia dianggap penting, terutama oleh generasi muda dan guru bahasa Inggris yang memahami dan mendukung ide terkait penggunaan teknologi di kelas, sebaliknya pada generasi yang lebih tua ada juga yang mengkritik dan meremehkan keberadaannya. Pertama-tama, ini dapat memenuhi kebutuhan individu siswa dan menerapkan berbagai metode dan pendekatan dapat dipenuhi dengan memperkenalkan materi digital. Yang ini memungkinkan adanya penyesuaian dengan harapan individu, minat atau kebutuhan para pembelajar bahasa dalam kelompok. Kegiatan semacam 
itu tidak hanya memancing pemikiran kreatif, tetapi juga mendorong siswa untuk mempraktekkan bahasa di dalam dan di luar kelas. Terlebih lagi, mereka mengekspos siswa pada praktik bahasa di lingkungan yang mereka kenal. Hal ini dapat membantu mereka untuk memecahkan hambatan bahasa karena mereka tidak merasa terisolasi lagi.

\section{Bialystok}

(1999:73),

menyatakan bahwa pelajaran bahasa Inggris dapat dipersonalisasi dan diarahkan di luar buku teks. Siswa mendapatkan kesempatan untuk menghadapi materi bahasa yang otentik. Mereka terpapar dengan realita dalam dunia nyata yang terkait dengan keterampilan berbahasa, dan oleh karena itu, mereka lebih mungkin untuk bertemu dengan banyak komunitas. Terlebih lagi, siswa akrab dengan cara mengumpulkan informasi dan materi yang bermanfaat, karena saat ini, mayoritas dari mereka menggunakan perangkat seperti ponsel pintar, komputer pribadi, dan komputer tablet di rumah. Selain itu, siswa lebih bersemangat untuk belajar dan mereka dapat tetap fokus lebih lama selama kelas, karena berbagai bahan yang tersedia mencegah siswa dari perasaan monoton dan kebosanan. Proses belajar mereka menjadi lebih efisien dan mandiri. Dengan menjelajah internet di rumah, para siswa mengembangkan kecepatan mereka dalam belajar bahasa dan menggunakan platform pengajaran tambahan yang membantu mereka untuk merevisi dan mengkonsolidasikan pengetahuan mereka. Pada akhirnya teknologi modern di kelas memungkinkan siswa untuk mengembangkan kemampuan yang dibutuhkan di tempat kerja masa depan mereka. Mereka memperoleh keterampilan praktis seperti penelitian dan pemikiran kritis yang penting pada era ini.

\subsection{Pengajaran Bahasa Inggris di Sekolah Dasar}

Pendidikan bahasa Inggris berkembang sangat pesat sebagai respon terhadap peran bahasa Inggris sebagai bahasa internasional. Bahasa Inggris pada tingkat dasar pertama kali diperkenalkan secara resmi di Indonesia pada tahun 1994 (Keputusan Menteri Pendidikan No. 060 / U / Kurikulum 1993 dan 1994). Sekolah memiliki wewenang untuk memasukkan bahasa Inggris sebagai subjek konten lokal dengan mempertimbangkan kondisi sekolah, orang tua, dan masyarakat. Maksud dan tujuan pengajaran bahasa Inggris dasar menurut Departemen Pendidikan adalah 1) untuk meningkatkan kemampuan dasar siswa keterampilan komunikasi bahasa Inggris dalam konteks sekolah, 2) untuk memotivasi minat siswa dalam belajar bahasa Inggris, dan 3) untuk memperluas perspektif siswa terhadap pentingnya belajar bahasa Inggris untuk meningkatkan daya saing mereka dalam masyarakat global. Area pembelajaran mencakup semua aspek keterampilan bahasa Inggris seperti mendengarkan, berbicara, membaca, dan menulis untuk memperkuat kemampuan komunikasi lisan bahasa Inggris. Ketrampilan menulis dan membaca diarahkan untuk mendukung keterampilan berbicara. Pendidikan bahasa Inggris menyebar sangat luas sebagai respon terhadap peran bahasa Inggris sebagai bahasa internasional. Memperkenalkan studi bahasa asing pada tahap awal seperti itu dibenarkan sebagai strategi untuk mendukung anak-anak dengan materi pembelajaran tambahan; strategi untuk meningkatkan kemajuan kognitif mereka dan pemahaman mereka terkait bahasa lain dan budaya juga.

Bahasa Inggris di tingkat dasar di Indonesia ditawarkan sebagai mata 
pelajaran elektif dan dikategorikan sebagai subjek konten lokal. Subjek elektif berarti bahwa itu tergantung pada kesiapan sekolah, terutama dengan sumber daya guru, sumber belajar dan kurikulum. Bahasa Inggris di sekolah dasar dimulai dari kelas 4 . Motivasi utama yang mendasari keputusan untuk memperkenalkan bahasa Inggris kepada pelajar usia sekolah dasar adalah status bahasa Inggris dan komitmen politik dan ekonomi Indonesia untuk menjaga hubungan dengan negara asing menggunakan bahasa Inggris. Selain alasan politik, permintaan orang tua juga memaksa sekolah untuk memberikan pendidikan bahasa Inggris (Yuwono, 2005:39). Orangtua menginginkan agar anak-anak mereka mencapai tingkat kemahiran bahasa Inggris yang tinggi dan mereka sadar bahwa belajar bahasa Inggris di usia dini mendukung anak-anak mereka untuk proses belajar yang lebih baik di tingkat yang lebih tinggi. Ada juga beberapa penelitian yang menunjukkan tentang pengajaran bahasa Inggris pada usia dini. Sebuah penelitian yang dilakukan di Jepang terkait dengan ELT di sekolah dasar mengungkapkan bahwa ada efek positif dari bahasa Inggris awal di negara tersebut. Ditemukan juga bahwa pendidikan bahasa Inggris awal membantu meningkatkan minat siswa terhadap bahasa Inggris dan memfasilitasi motivasi belajar bahasa Inggris setelah memasuki sekolah menengah pertama.

Di sisi lain, masih banyak pertanyaan dari para pemangku kepentingan tentang keberhasilan belajar bahasa Inggris di tingkat ini. Beberapa studi terkait pembelajaran bahasa Inggris telah mengungkapkan bahwa pembelajaran bahasa Inggris di sekolah dasar, terutama di kelas-kelas di Indonesia, belum berhasil (Septy,
2000:76). Sejak pertama kali diajarkan, pengajaran bahasa Inggris untuk sekolah dasar telah menemui banyak masalah. Masalahnya diidentifikasi sebagai kualifikasi guru, ketersediaan waktu, jumlah siswa, dan sumber daya serta fasilitas yang tersedia (Yuwono, 2005:14). Selanjutnya, kualifikasi guru adalah tantangan pendidikan yang paling kontroversial karena menjadi faktor utama yang mempengaruhi keberhasilan dan kegagalan siswa dalam belajar (Huang dalam Chen 2006:13). Mengajar Bahasa Inggris kepada pelajar usia sekolah dasar sebenarnya membutuhkan pelatihan teori dan praktik yang tepat (Kirkgoz, 2008:17). Merupakan keyakinan yang salah bahwa guru manapun dapat mengatasi semua aspek bahasa Inggris yang bervariasi tanpa pelatihan tambahan atau saran spesialis (Bullock dalam Lookwood 1996:52). Guru bahasa Inggris di tingkat dasar harus memahami bahwa mereka memainkan peran utama dalam menghasilkan keberhasilan siswa dalam belajar karena siswa di kelas ini masih bergantung pada instruksi guru. Guru diharapkan untuk dapat menyajikan praktik pengajaran bahasa Inggris yang memungkinkan: 1) meningkatkan kesadaran siswa akan bahasa asing, 2) meningkatkan minat dan motivasi siswa terhadap bahasa Inggris, 3) mendorong penggunaan siswa dari target bahasa dalam komunikasi seharihari, 4) membantu siswa mengembangkan strategi yang tepat dan 5) menciptakan sikap positif terhadap pembelajaran bahasa Inggris.

Pengenalan bahasa Inggris di sekolah dasar berhubungan dengan faktor usia. Salah satu poin mendasar adalah mengeksploitasi plastisitas yang lebih besar dari otak anak kecil (Bialystok dan Hakuta, 1999: 17). Singleton dan Ryan (2001:46) 
mempresentasikan sebuah survei tentang alasan pengajaran bahasa Inggris di tingkat dasar yang bergantung pada klaim waktu terbaik untuk belajar bahasa, mereka adalah: 1) Memberikan lebih banyak kesempatan kepada anak-anak memahami budaya asing agar lebih toleran kepada orang lain, 2) Memaksimalkan waktu belajar untuk bahasa, lebih awal anak memulai lebih banyak waktu yang anak dapatkan, 3) Dimulai dengan instruksi bahasa asing tahap awal, sehingga pada bahasa tingkat teks dapat digunakan sebagai media instruksional. Kita dapat mengatakan bahwa pelajar usia anak sekolah dasar memiliki lebih banyak kesempatan daripada orang dewasa untuk belajar bahasa karena mereka memiliki sifat yang lebih menguntungkan. Saran lain yang diusulkan oleh Brumfit (1991:7) untuk pembelajaran yang lebih baik adalah bahwa otak lebih mudah beradaptasi sebelum pubertas daripada sesudahnya, dan bahwa akuisisi bahasa dimungkinkan tanpa kesadaran diri pada usia dini. Bahwa anak-anak memiliki lebih sedikit sikap negatif terhadap bahasa dan budaya asing daripada orang dewasa, dan akibatnya mereka lebih termotivasi daripada orang dewasa. Bahwa pembelajaran bahasa anak-anak lebih erat terintegrasi dengan komunikasi nyata karena lebih bergantung pada lingkungan fisik langsung daripada bahasa orang dewasa. Bahwa anak-anak mencurahkan banyak waktu untuk belajar bahasa, dibandingkan dengan orang dewasa dan mereka lebih baik jika mereka melakukan lebih banyak hal. Meskipun penelitian tentang pembelajaran bahasa juga telah menyajikan kesimpulan yang berbeda tentang penguasaan bahasa anak-anak yang mengatakan bahwa orang dewasa adalah pembelajar yang lebih baik dan lebih cepat, pada kenyataannya, pembelajaran bahasa itu kompleks dan membutuhkan dukungan guru yang kuat selama beberapa tahun (Bialystok \& Hakuta, 1999:28), tetapi pengenalan bahasa asing dianggap sebagai tindakan yang menguntungkan untuk tingkat penguasaan bahasa lebih lanjut. Pendidikan dasar dianggap sebagai tingkat strategis untuk mulai menerapkan kebijakan baru tentang pendidikan. Salah satu kebijakan adalah memperkenalkan mata pelajaran baru di sekolah seperti bahasa Inggris sebagai bahasa asing pada tingkat strategis untuk mulai menerapkan kebijakan baru tentang pendidikan.

\section{SIMPULAN}

Memang benar bahwa salah satu tujuan akhir pengajaran bahasa inggris berbasis teknologi multimedia adalah untuk meningkatkan motivasi dan minat belajar siswa, yang dapat menjadi cara praktis untuk melibatkan mereka dalam pembelajaran bahasa. Konteks kegiatan ini harus didasarkan pada keterbukaan dan aksesibilitas bahan ajar dan informasi. Selama proses pengoptimalan pengajaran bahasa Inggris berbasis teknologi multimedia, siswa diharapkan tidak terlalu bergantung pada bahasa ibu mereka, tetapi akan termotivasi dan dituntun untuk berkomunikasi satu sama lain. Berkaitan dengan perkembangan teknologi, para pakar sepakat dan percaya bahwa di masa depan, penggunaan teknologi berbasis multimedia dalam pengajaran bahasa Inggris akan dikembangkan lebih lanjut. Proses pembelajaran bahasa Inggris akan lebih berpusat pada siswa tetapi lebih memakan waktu. Oleh karena itu, hal itu menjanjikan bahwa kualitas pengajaran dan keterampilan siswa akan ditingkatkan, yang berarti bahwa kompetensi komunikatif siswa 
akan dikembangkan lebih lanjut. Kesimpulannya, proses ini dapat dioptimalkan untuk meningkatkan kemampuan siswa dan keterampilan bahasa praktis mereka. Pembatasan beberapa masalah pada area teknologi multimedia dapat digunakan secara efektif di ruang kelas dengan pengetahuan komputer yang tepat di pihak guru.

\section{DAFTAR PUSTAKA}

Arifah, A. 2014. Study on the Use of Technology in ELT Classroom: Teachers' Perspective. M.A. Thesis, Department of English and Humanities, BRAC University, Dhaka, Bangladesh.

Baytak, A., Tarman, B., \& Ayas, C. 2011. Experiencing Technology Integration in Education: Children's Perceptions. International Electronic Journal of Elementary Education, 3(2), 139-151.

https://www.iejee.com/index.php/ IEJEE/article/view/233. Date accessed: June $17^{\text {th }}, 2018$.

Bialystok, E. and K. Hakuta 1999. Confounded Age: Linguistic and Cognitive Factors in Age Differences for Second Language Acquisition: Second Language Acquisition and the Critical Period Hypothesis. in D. Birdsong. (ed). New Jersey, Lawrence Erlbaum Associates.

Brumfit C, Mooh J, et al., Eds. 1984. Teaching English to Children: From Practice to Principle. England, Longman Group, Ltd.

Costley, K. C. 2014. The Positive Effects of Technology on Teaching and Student Learning. Arkansas Tech University.

Dockstader, J. 2008. Teachers of the $21^{\text {st }}$ Century Know the What, Why, and How of Technology
Integration. Retrieved from http://thetech.mit.edu/Chemicool.

Eady, M. J., \& Lockyer, L. 2013. Tools for Learning: Technology and Teaching Strategies: Learning to Teach in the Primary School. Queensland University of Technology, Australia. pp. 71-89. https://scholars.uow.edu.au/displa y/publication76376.

Eaton, S. E. 2010. Global Trends in Language Learning in the Twenty-First Century. Calgary, Canada: Onate Press. https://files.eric.ed.gov/fulltext/E D510276.pdf.

Gençlter, B. 2015. How does Technology Affect Language Learning Process at an Early Age? Procedia - Social and Behavioral Sciences, 199(2015), 311 - 316. doi: 10.1016/j.sbspro. 2015.07.552.

Keser, H., Uzunboylu, H., \& Ozdamli, F. 2012. The Trends in Technology Supported Collaborative Learning Studies in $21^{\text {st }}$ Century. World Journal on Educational Technology, 3(2), 103-119.

Kirkgoz, Y. 2006. Teaching EFL at the Primary Level in Turkey. Teaching English as a Foreign Language in Primary School. in M. L. McCloskey, Janet Orr \&M. Dolitsky. Illinois, Capitol Communication System, Inc.

Larsen- Freeman, D., \& Anderson, M. 2011. Techniques and Principles in Language Teaching. Oxford: OUP.

Parvin, R. H., \& Salam, S. F. 2015. The Effectiveness of Using Technology in English Language Classrooms in Government Primary Schools in Bangladesh. FIRE: Forum for International 
Research in Education, 2(1), 4759. http://preserve.lehigh.edu/fire/ vol2/iss $1 / 5$.

Patel, C. 2013. Use of Multimedia Technology in Teaching and Learning Communication Skill: An Analysis. International Journal of Advancements in Research \& Technology, 2(7), 116-123.

Pourhossein Gilakjani, A. 2014. A Detailed Analysis over Some Important Issues towards Using Computer Technology into the EFL Classrooms. Universal Journal of Educational Research, 2(2), 146-153. doi: 10.13189/ujer.2014.020206.

Pourhossein Gilakjani, A. 2017. A Review of the Literature on the Integration of Technology into the Learning and Teaching of English Language Skills. International Journal of English Linguistics, 7(5), 95-106. doi: https://doi.org/10.5539/ijel.v7n5p 95.

Sabzian, F., Pourhossein Gilakjani, A., \& Sodouri, S. 2013. Use of Technology in Classroom for Professional Development. Journal of Language Teaching and Research, 4(4), 684-692. doi:10.4304/jltr.4.4.684-692.

Septy, P. 2000. Assumptions and Evidences about Introducing English in Indonesian Primary School. LCS Article. Retrieved June $17^{\text {th }}, 2018$..

Solanki, D., \& Shyamlee1, M. P. 2012. Use of Technology in English Language Teaching and Learning: An Analysis. 2012 International Conference on Language, Medias and Culture IPEDR vol. 33(2012)@(2012)IACSIT Press, Singapore. 150-156.

Susikaran, R. S. A. 2013. The Use of Multimedia in English Language Teaching. Journal of Technology for $\quad$ ELT, 3(2). https://sites.google.com/site/journ aloftechnologyforelt/ archive/3-2april-2013/1-the-use-ofmultimedia-inenglish-languageteaching.

Yuwono, G. 2005. English Language Teaching in Decentralized Indonesia: Voices from the Less Privileged Schools. AARE 2005 International Education Research Conference. 